\title{
Carbon Uptake Rates of Sea Ice Algae and Phytoplankton under Different Light Intensities in a Landfast Sea Ice Zone, Barrow, Alaska
}

\author{
SANG H. LEE,,$^{1,2,3}$ TERRY E. WHITLEDGE ${ }^{1}$ and SUNG-HO KANG ${ }^{2}$
}

(Received 25 May 2007; accepted in revised form 3 December 2007)

\begin{abstract}
To determine whether nitrogen or light exerts the most control for the rates of carbon production of ice algae and phytoplankton under the ice, nitrogen addition $\left(\mathrm{NO}_{3}\right.$ or $\left.\mathrm{NH}_{4}\right)$ and light increment experiments were executed on the landfast sea ice of Barrow, Alaska, during the 2003 growing season by using a ${ }^{13} \mathrm{C}-{ }^{15} \mathrm{~N}$ dual isotope tracer technique. The productivity of the bottom sea ice algae and phytoplankton at Barrow in 2003 was limited mainly by low light levels (approximately $0.3 \%$ of the surface irradiance) at the bottom under the snow-covered sea ice. The carbon and nitrate uptake rates of ice algae and phytoplankton increased as the incubation depth in the ice hole decreased and light intensity increased. In addition, under higher light conditions, the relative production of proteins of the bottom ice algae decreased, whereas the lipid proportion increased. The higher level of lipid synthesis of the ice algae might be significant to the nutrition of zooplankton and benthos because lipids are the most energy-dense biomolecules.
\end{abstract}

Key words: ice algae, phytoplankton, carbon production, lipid synthesis, macromolecules, landfast sea ice, Barrow

RÉSUMÉ. Afin de déterminer si c'est l'azote ou la lumière qui exerce le plus grand contrôle sur les taux de production de carbone émanant des algues de glace et du phytoplancton sous la glace, des expériences consistant en l'ajout différentiel d'azote $\left(\mathrm{NO}_{3}\right.$ ou $\mathrm{NH}_{4}$ ) et de lumière ont été effectuées sur la glace de mer côtière de Barrow, en Alaska, pendant la saison de croissance de 2003 grâce à une technique de traceurs d'isotopes mixtes de ${ }^{13} \mathrm{C}-{ }^{-15} \mathrm{~N}$. La productivité des algues de glace de mer et de phytoplancton de fond à Barrow en 2003 a été surtout restreinte par les faibles taux de lumière (environ 0,3\% de l'éclairement de la surface) au fond, sous la glace de mer couverte de neige. Les taux d'absorption de carbone et d'azote chez les algues de glace et le phytoplancton augmentaient au fur et à mesure que la profondeur d'incubation du trou de glace diminuait et que l'intensité lumineuse s'intensifiait. De plus, lorsque les conditions de luminosité étaient plus grandes, la production relative de protéines des algues de glace de fond diminuait, tandis que la proportion de lipides grimpait. Le taux plus élevé de synthèse des lipides des algues de glace pourrait revêtir de l'importance dans la nutrition du zooplancton et du benthos parce que les lipides sont les biomolécules les plus denses en énergie.

Mots clés : algues de glace, phytoplancton, production de carbone, synthèse des lipides, macromolécules, glace de mer côtière, Barrow

Traduit pour la revue Arctic par Nicole Giguère.

\section{INTRODUCTION}

Recently, the Arctic has been changing at a very rapid rate. Higher temperatures have decreased the extent and thickness of perennial sea ice in the Arctic Ocean over the past 40 years and have produced more open water (Rothrock et al., 1999, 2003; Vinnikov et al., 1999). Serreze et al. (2003) and Comiso (2006) found that Arctic sea ice extent and area during 2002-05 were at their lowest levels recorded since 1978. The results from Laxon et al. (2003) suggest that continued increase in the length of the melt season will cause further thinning of Arctic sea ice. These changes in ice thickness and extent may alter light conditions through the sea ice and thus carbon and nitrogen production rates, as well as the physiological conditions of sea ice algae and phytoplankton. As a consequence of these changes, the seasonal distributions, geographic ranges, and nutritional structure of zooplankton have been projected to be altered (Tynan and DeMaster, 1997). More studies of seasonal and annual production rates and physiological conditions of ice algae and water column phytoplankton are needed to improve our understanding of the impacts of current and future climate changes on the marine ecosystems in Arctic communities.

Sea-ice algae at the bottom of first-year ice account for a substantial proportion of the primary production in the Arctic Ocean (Horner and Schrader, 1982; Gosselin et al., 1997; Mock and Gradinger, 1999) as well as in the Antarctic

\footnotetext{
${ }^{1}$ Institute of Marine Science, University of Alaska Fairbanks, Fairbanks, Alaska 99775-7220, USA

${ }^{2}$ Korea Polar Research Institute (KOPRI), KORDI, Songdo Techno Park, 7-50, Songdo-dong, Yeonsu-gu, Incheon 406-840, Korea

${ }^{3}$ Corresponding author: sanglee@kopri.re.kr

(C) The Arctic Institute of North America
} 
oceans (Arrigo et al., 1997; Lizotte, 2001). The contribution of ice algae to total primary production ranges from less than $1 \%$ in the coastal regions (Alexander and Chapman, 1981) up to around $60 \%$ in the central ice-covered ocean of the Arctic (Gosselin et al., 1997). The ecological impact of ice algal production is important to the secondary production because it can increase the primary production season by up to three months in spring (Apollonio, 1965; Alexander, 1980; Legendre et al., 1981) and thus provide an initial food resource for zooplankton grazers in polar oceans (Michel et al., 1996; Lizotte, 2001).

There have been many studies to determine which factors control the production of ice microalgae in both the Arctic and the Antarctic oceans. A number of physical and chemical factors, such as light and nutrients, limit primary production of phytoplankton in the water column or ice algae within sea ice in polar oceans (Arrigo, 2003). It is difficult to determine the specific factors that control primary production. However, the production and biomass of phytoplankton or ice algae in the Arctic Ocean are controlled mainly by light (Horner and Schrader, 1982; SooHoo et al., 1987; Cota and Smith, 1991), or nutrients (Gosselin et al., 1990; Smith et al., 1997), or both, depending on the region and the stage of algae development (Smith et al., 1988; Taguchi and Smith, 1997). For example, some studies concluded that low light intensities that are transmitted through the snow-covered sea ice were a major factor influencing the production of bottom-ice communities (Horner and Schrader, 1982; SooHoo et al., 1987; Cota and Smith, 1991). Other studies showed that the addition of nutrients stimulated the production rate, evidence that the availability of macronutrients such as nitrogen and silicate was the main limit on the production of ice algae. Stimulation of the biochemical characteristics and the physiological status of ice algae also indicated nutrient-limited conditions (Gosselin et al., 1990; Smith et al., 1997). However, Lavoie et al. (2005) confirmed that light was the main limiting factor at the beginning of the growth season and nutrients became limiting factors in later stages.

The primary objective of this study was to determine whether nitrogen $\left(\mathrm{NO}_{3}\right.$ or $\left.\mathrm{NH}_{4}\right)$ or light exerts the most control on the production rates of ice algae in the bottom layer of sea ice and phytoplankton under the ice in a landfast sea-ice zone, Barrow, Alaska. The second objective was to evaluate possible changes in the physiological condition of sea-ice algae (and thus light intensities) at different depths in an ice hole by determining carbon allocation into different macromolecules as photosynthetic end products.

\section{MATERIALS AND METHODS}

\section{Study Area}

Sampling was conducted on smooth landfast first-year sea ice located approximately $1.0 \mathrm{~km}$ offshore from the
Naval Arctic Research Laboratory, Barrow, Alaska $\left(71^{\circ} 20^{\prime} \mathrm{N}, 156^{\circ} 39^{\prime} \mathrm{W}\right)$ (Fig. 1). The sampling site was located approximately midway between the shore and the active pressure ridge. The water depth at the sampling sites was approximately $4-5 \mathrm{~m}$ below the bottom of the ice. The landfast sea ice attached to the coastal land is formed every year. Currents in this coastal area vary seasonally, and the current speed, estimated by Alexander et al. (1974) in ice-free periods during summer, was between 0.5 and 4.0 knots.

In situ ice algal and phytoplankton productivity incubations were undertaken on the landfast sea ice at Barrow on 28 April, 20 May, and 9 June 2003. In general, ice algae in the study area started to grow in early March and declined in late May (Lee, 2005). Photosynthetic carbon allocations of different macromolecules were analyzed from the ice algae productivity incubation on 28 April, when the algal biomass was highest.

\section{Inorganic Nutrient and Chlorophyll-a Analysis}

Water samples for nutrient and chlorophyll-a analysis were collected at $1 \mathrm{~m}$ increments from the bottom of the ice to $4 \mathrm{~m}$ depth using a Kemmerer water sampler $(1.2 \mathrm{~L})$ through ice holes and kept frozen at $-20^{\circ} \mathrm{C}$ until analysis. For nutrients in ice, three or four ice cores were obtained within $1 \mathrm{~m}$ diameter distance by $8 \mathrm{~cm}$ diameter SIPRE corers, and each $10 \mathrm{~cm}$ section of the ice cores was cut off and melted in the dark at room temperature. This procedure could potentially affect $\mathrm{NH} 4+$ concentration in the melted-ice samples through nutrient regeneration. The bottom $10 \mathrm{~cm}$ section of the ice core was cut off again at $3 \mathrm{~cm}$ from the bottom, since most of the ice algal biomass was concentrated in the bottom $3 \mathrm{~cm}$ of the ice cores. After complete melting, each sample was mixed and divided into nutrient and chlorophyll-a aliquots. The water for nutrient analysis was frozen without filtering, and concentrations of inorganic nutrients (nitrate, ammonium, silicate, and phosphate) were determined in the laboratory using an automated nutrient analyzer (ALPKEM), following methods of Whitledge et al. (1981). Samples for the determination of total chlorophyll-a concentration were filtered onto Whatman GF/F filters $(24 \mathrm{~mm})$. The filters were frozen and returned to the laboratory for analysis. The filters were subsequently extracted in a 3:2 mixture of 90\% Acetone and DMSO (Webb et al., 1992) for 24 hours and centrifuged as described by Parsons et al. (1984). Concentrations of chlorophyll-a were measured using a Turner Designs model 10-AU fluorometer that had been calibrated with commercially purified chlorophyll-a preparations. After chlorophyll-a concentrations had been measured, $100 \mu \mathrm{l}$ of $10 \% \mathrm{HCl}$ solution was added into the extracted solution and stored in a test tube rack for about 90 seconds to degrade chlorophyll-a into phaeopigments. A final fluorescence reading was taken after the acidification. The methods and calculations for chlorophyll-a and phaeopigments were based on Parsons et al. (1984). 


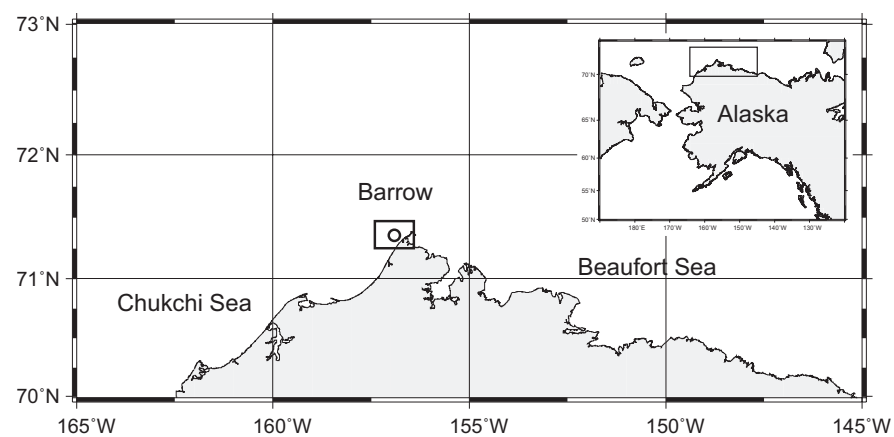

FIG. 1. Location of the primary sampling site near the Naval Arctic Research Laboratory at Barrow, Alaska.

\section{Light Intensity Experiments}

Three or four bottom $3 \mathrm{~cm}$ sections of ice containing ice algae were obtained by SIPRE corers, distributed into five polycarbonate incubation bottles $(460 \mathrm{ml})$, and topped up with $400 \mathrm{ml}$ of filtered seawater. To measure the uptake rates of carbon and nitrogen, heavy isotope-enriched (98\% to $99 \%$ ) solutions of $\mathrm{H}^{13} \mathrm{CO}_{3}, \mathrm{~K}^{15} \mathrm{NO}_{3}$ or ${ }^{15} \mathrm{NH}_{4} \mathrm{Cl}$ were added to the bottles at concentrations of $\sim 0.3 \mathrm{mM}\left({ }^{13} \mathrm{CO}_{2}\right)$, $\sim 1.0 \mu \mathrm{M}\left({ }^{15} \mathrm{NO}_{3}\right)$ and $\sim 0.1 \mu \mathrm{M}\left({ }^{15} \mathrm{NH}_{4}\right.$ ) (Dugdale and Goering, 1967; Hama et al., 1983). For the phytoplankton productivity experiment, water was collected from $2 \mathrm{~m}$ depth below the bottom of the ice. Two sets of bottles for ice algae and phytoplankton were tied (facing upwards) to each anchor line and deployed at the different depths $(0.1,0.5,1.0,1.4$, and $3.5 \mathrm{~m}$ below the surface of the top ice; Fig. 2a) through each ice hole. The locations at various depths in an ice hole had different light intensities. The light experienced at each depth was measured with a LICOR $4 \pi$ light sensor facing upward and a surface radiation reference (LI-190 quantum sensor), which was used to provide estimates of light intensity for each of the different incubation depths. We note that these estimates are only relative as we did not account for attenuation by the incubation bottles and their contents or changes made to the surface between light measurements and deployment of the incubation set-up. During the incubation, three layers of ice cores covered the top of the holes to limit direct light penetration. The samples were incubated at in situ water temperature $\left(\sim-1.5^{\circ} \mathrm{C}\right)$ and light for $4-5 \mathrm{hrs}$ around local noon. They were then retrieved and brought to the lab in a dark, insulated box for filtration. The weather was mostly cloudy during the incubation hours. On 28 April 2003, because ice algal biomass in the melted water of ice productivity bottles was so high, only $50 \mathrm{ml}$ from each bottle was filtered onto $24 \mathrm{~mm} \mathrm{GF/F} \mathrm{filters} \mathrm{for}$ carbon and nitrogen uptake rates, and the rest of the water was filtered onto $47 \mathrm{~mm} \mathrm{GF/F}$ filters for photosynthetic carbon allocation of ice algae under different light intensities. The filters were immediately frozen at $-20^{\circ} \mathrm{C}$ and preserved for mass spectrometric analysis at the stable isotope laboratory of the University of Alaska Fairbanks
(UAF). Particulate organic carbon and nitrogen and abundance of ${ }^{13} \mathrm{C}$ and ${ }^{15} \mathrm{~N}$ were determined in the Finnigan Delta $+\mathrm{XL}$ mass spectrometer after $\mathrm{HCl}$ fuming overnight to remove carbonate. Carbon and nitrogen production rates were calculated according to Hama et al. (1983) and Dugdale and Goering (1967).

For comparison, $\alpha$ (photosynthetic efficiency, mg C $\left.(\mathrm{mg} \mathrm{Chl} \mathrm{a})^{-1}\left(\mu \mathrm{E} \mathrm{m}^{-2} \mathrm{~s}^{-1}\right)^{-1} \mathrm{~h}^{-1}\right)$ and $\mathrm{I}_{\mathrm{k}}$ (photoacclimation parameter) in Figure 3 from the light enhancement experiments were calculated using the equation of the light saturation curve of photosynthesis (Platt et al., 1980):

$$
P^{B}=P_{S}^{B}\left[1-\exp \left(-\alpha I / P_{S}^{B}\right)\right] \exp \left(-\beta I / P_{S}^{B}\right)
$$

where $P^{B}\left(\mathrm{mg} \mathrm{C}(\mathrm{mg} \mathrm{Chl} \mathrm{a})^{-1} \mathrm{~h}^{-1}\right)$ indicates that the carbon fixation rate $\mathrm{P}\left(\mathrm{mg} \mathrm{C} \mathrm{h}^{-1}\right)$ is normalized to the chlorophyll biomass $\mathrm{B}(\mathrm{mg} \mathrm{Chl} \mathrm{a}), P^{B}{ }_{S}\left(\mathrm{mg} \mathrm{C}(\mathrm{mg} \mathrm{Chl} \mathrm{a})^{-1} \mathrm{~h}^{-1}\right)$ is the maximum fixation rate, and $\beta$ (same unit as $\alpha$ ) describes the strength of the photoinhibition, and $I\left(\mu \mathrm{E} \mathrm{m}^{-2} \mathrm{~s}^{-1}\right)$, the strength of photosynthetically active radiation (Platt et al., 1980). Light intensities were relative estimates; therefore, the parameters derived from fitting equation 1 will be relative as well.

\section{Nutrient Concentration Experiments}

To determine the effects of ammonium and nitrate concentration on carbon uptake rates of ice algae and phytoplankton in the water column, in situ productivity incubations under different concentrations were undertaken in parallel with the light increment experiments on 28 April, 20 May, and 9 June 2003. We used the same collection methodology described for inorganic nutrient and chlorophyll-a analysis to obtain samples for productivity measurements. We added differing amounts of concentrated $\mathrm{NO}_{3}$ solution $(10 \mathrm{mM})$ into six bottles and $\mathrm{NH}_{4}(5 \mathrm{mM})$ into another six bottles to measure ice algae productivity. A second set of 12 bottles was prepared to measure phytoplankton productivity. Concentrations of injected nutrients for the six incubation levels were (1) 0 , (2) $2.2 \mu \mathrm{M}$, (3) $4.4 \mu \mathrm{M}$, (4) $6.5 \mu \mathrm{M}$, (5) $8.7 \mu \mathrm{M}$, and (6) $10.9 \mu \mathrm{M}$, except that the concentration of $\mathrm{NO}_{3}$ added at level 6 was $13.0 \mu \mathrm{M}$ for ice algal incubation. Then ${ }^{13} \mathrm{C}$ isotope tracer was added to all the bottles. After the water in each bottle was well mixed, approximately $20 \mathrm{ml}$ water from each bottle was taken for initial nutrient concentrations before the incubations were started. Ice algal bottles were then deployed below the ice, and the bottles for phytoplankton were deployed about $2 \mathrm{~m}$ below the ice (Fig. 2b). The bottles were ordered top-to-bottom along the rope from lowest to highest amount of nutrients. After 4-5 hrs incubation, the bottles were retrieved and brought to the lab in a dark, insulated box for filtration. Another $20 \mathrm{ml}$ water was taken for the final measurement of nutrient concentration, and the rest of the water was filtered for measurement of carbon uptake rates. 

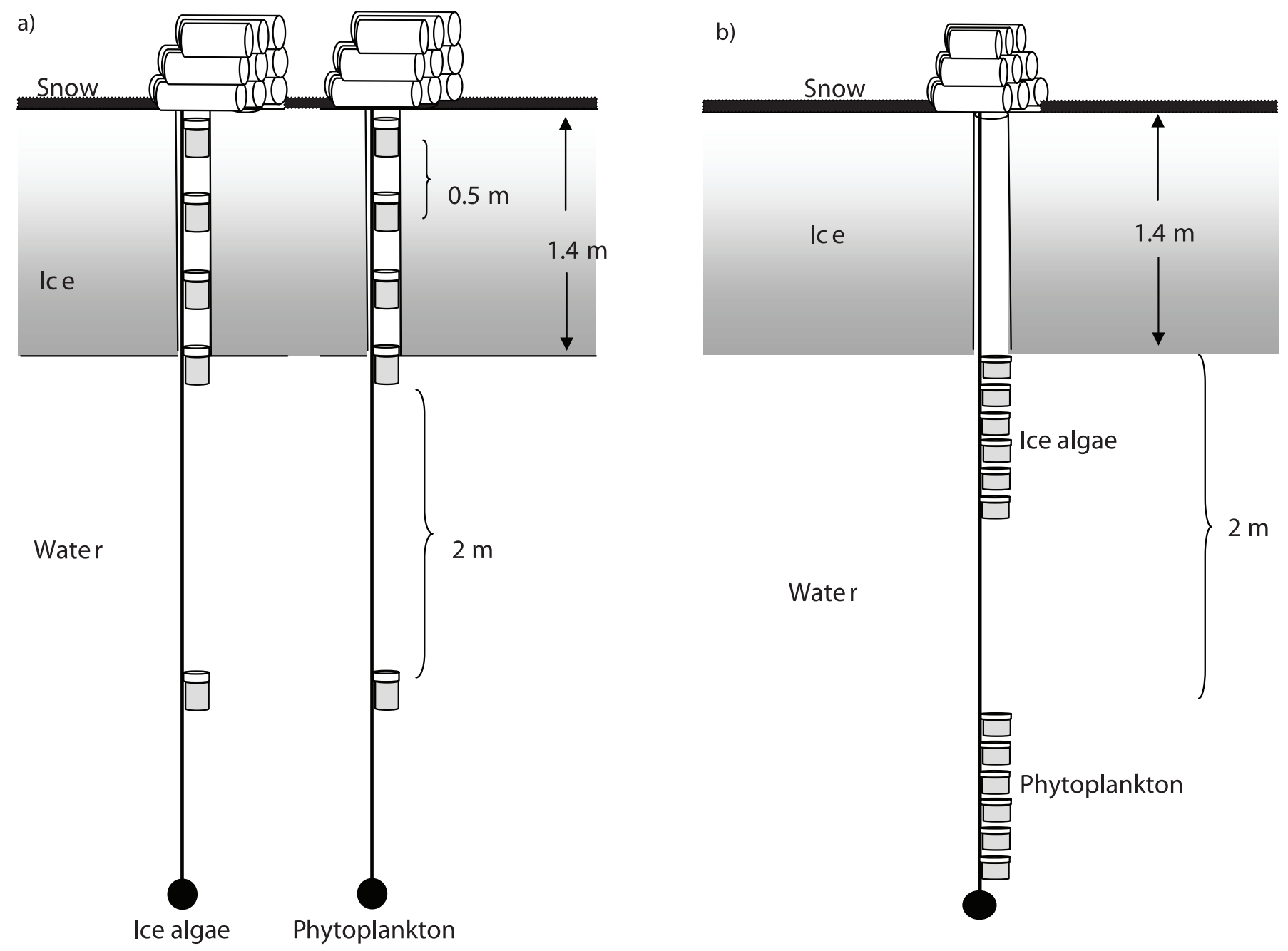

FIG. 2. Experimental set-up for carbon and nitrogen uptakes of ice algae and phytoplankton under (a) different light intensities at different depths (0.1, 0.5, 1.0, and $1.4 \mathrm{~m}$ ) of an ice hole and $2 \mathrm{~m}$ water depth under the ice and (b) different nutrient enrichments.

\section{Photosynthetic Carbon Allocation in Ice Algae Community}

To evaluate the changes in the photosynthetic carbon allocation of the ice algae community under different light conditions, we analyzed relative rates of production of different macromolecules from the ice algal productivity experiment on 28 April 2003, when the bottom ice algal biomass was sufficiently large to conduct the experiment. The differential extractions of macromolecular classeslow-molecular-weight metabolites (LMWM), lipids, proteins, and polysaccharides-were performed using the method of Li et al. (1980). The filters with particulate material were cut into small pieces and transferred into test tubes. Three $\mathrm{ml}$ of chloroform-methanol $(2: 1 \mathrm{v} / \mathrm{v})$ were added to the test tube and ultrasonified for 20-30 minutes to extract lipids and LMWM from the ice algae on the filters. After the extraction, the suspension was collected by a Pasteur pipette and stored in new test tubes. This extraction procedure was repeated three times. When the extractions were completed, $1.5 \mathrm{ml}$ distilled water was added to the solution in the tube. The mixture was shaken vigorously three or four times for 2-3 minutes and set up for separation of the chloroform phase for lipids and the methanol-water phase for LMWM. The filters were resuspended in $4 \mathrm{ml}$ of 5\% TCA (trichloroacetic acid) and heated at $95^{\circ} \mathrm{C}$ for $20-30$ minutes. The suspension was collected with a Pasteur pipette for extraction of polysaccharides (TCA-soluble). The filters were extracted with a further $4 \mathrm{ml}$ of $5 \%$ TCA one more time, washed with 5\% TCA solution, and saved for protein analysis (TCAinsoluble). Abundances of ${ }^{13} \mathrm{C}$ for different macromolecular classes were determined in the Finnigan Delta+XL mass spectrometer at UAF. A separate measure of total carbon assimilation per each class was not made for this study because total carbon abundance was too high for the mass spectrometer to measure. So, the data from the results do not indicate absolute carbon production, but relative carbon assimilation for comparison.

\section{RESULTS}

Physical parameters at the sampling sites on the landfast sea ice at Barrow on 28 April, 20 May, and 9 June 2003 are 
TABLE 1. Physical parameters and chlorophyll-a concentrations in the bottom ice $(3 \mathrm{~cm})$ at the sampling sites on the land fast-sea ice at Barrow in 2003.

\begin{tabular}{|c|c|c|c|}
\hline Date & 28 April & 20 May & 9 June \\
\hline Air temperature $\left({ }^{\circ} \mathrm{C}\right)^{1}$ & -3 & 0 & 1 \\
\hline Mean snow depth $(\mathrm{cm})$ & 7.5 & 20 & 3.5 \\
\hline Ice thickness $(\mathrm{cm})$ & 138 & 140 & 140 \\
\hline Temperature $\left({ }^{\circ} \mathrm{C}\right)$ in water column $(2 \mathrm{~m})^{2}$ & -1.6 & -1.6 & -1.3 \\
\hline Salinity in water column $(2 \mathrm{~m})^{2}$ & 32 & 32 & 31 \\
\hline Temperature $\left({ }^{\circ} \mathrm{C}\right)$ in the bottom section $(3 \mathrm{~cm})$ of the ice ${ }^{1}$ & -1 & -2.5 & -0.6 \\
\hline Bulk salinity in the bottom section $(3 \mathrm{~cm})$ of the ice ${ }^{2}$ & 13 & 8.4 & 5.3 \\
\hline Light intensity $\left(\mu \mathrm{E} \mathrm{m}^{-2} \mathrm{~s}^{-1}\right)$ at the ice-water interface ${ }^{3}$ & 6.7 & 3.4 & 14.9 \\
\hline Ice algal chlorophyll-a (mg Chl-a m-2) & 26.9 & 4.9 & 1.2 \\
\hline
\end{tabular}

${ }^{1}$ Air and ice temperatures were measured with a traceable thermometer (VWR, accuracy of $\pm 2^{\circ} \mathrm{C}$ ).

${ }^{2}$ Salinity and temperature for water column and bulk salinity for the bottom section of the ice were measured with a YSI model 85 meter (accuracy of $\pm 2 \%$ ).

${ }^{3}$ Since light intensity below the bottom sea ice with ice algal layer was measured only once (at around noon) during the productivity experiment, care must be taken when comparing these results to those from other studies.

summarized in Table 1. The ice thickness was similar, whereas the snow depth fluctuated between observation times. The chlorophyll-a concentration of the bottom ice algae was highest on 28 April 2003. Temperature and salinity in the water column $(2 \mathrm{~m})$ under the sea ice were rather constant, although slight changes were noted at the end of the season.

\section{Light Intensity}

The light intensity down the ice hole $($ diameter $=9 \mathrm{~cm})$ decreased rapidly from the surface to the $10 \mathrm{~cm}$ depth of the ice hole. The light level at $10 \mathrm{~cm}$ depth ranged from $10.3 \%$ to $18.5 \%$ of the incident light at the surface from 28 April to 9 June 2003. Most light was attenuated at the surface of ice covered by snow $(3.5-20.0 \mathrm{~cm})$. Under the ice, the light intensity in the water column decreased slowly with depth. The mean light at the ice-water interface was about $0.3 \%( \pm 0.1 \%)$ of the incident surface irradiance (Table 1).

\section{Inorganic Nutrient Concentrations}

Since the water under the ice was well mixed and the concentrations of nutrients were essentially constant through the $4 \mathrm{~m}$ water column to the bottom at Barrow during the observation period, the concentrations at $2 \mathrm{~m}$ water depth below the ice are presented in Table 2. $\mathrm{NO}_{3}$ concentrations increased slightly (from 6.5 to $7.3 \mu \mathrm{M}$ ) from 28 April to 20 May, but then decreased to $2.2 \mu \mathrm{M}$ on 9 June. $\mathrm{NH}_{4}$ concentrations decreased steadily from $3.2 \mu \mathrm{M}$ on 28 April to $0.8 \mu \mathrm{M}$ on 9 June, whereas the concentrations of $\mathrm{SiO}_{4}$ increased from $24.8 \mu \mathrm{M}$ on 28 April to $30.4 \mu \mathrm{M}$ on 20 May and then decreased to $15.8 \mu \mathrm{M}$ on 9 June 2003. The concentration of $\mathrm{PO}_{4}$ in the water was $1.5 \mu \mathrm{M}$ on 28 April and kept decreasing.

In contrast, the $\mathrm{NO}_{3}$ concentration from the bottom $3 \mathrm{~cm}$ section of ice was very high $(45.8 \mu \mathrm{M})$ on 28 April (Table 2$)$ when the chlorophyll-a concentration was highest (Table 1). The concentration on 28 April decreased rapidly to $0.3 \mu \mathrm{M}$ on 9 June. The $\mathrm{NH}_{4}$ concentrations decreased from $8.6 \mu \mathrm{M}$ on 28 April to $3.5 \mu \mathrm{M}$ on 20 May and then increased to $10.0 \mu \mathrm{M}$ on 9 June, while the $\mathrm{SiO}_{4}$ concentrations decreased gradually from $12.8 \mu \mathrm{M}$ on 28 April to $2.8 \mu \mathrm{M}$ on 9 June. The concentration of $\mathrm{PO}_{4}$ decreased rapidly and was undetectable on 9 June 2003. Since the nutrient concentrations were measured after the ice samples had melted completely, these concentrations for the ice should be considered minimal (Horner, 1985). In addition, Lavoie et al. (2005) showed with a model that nutrient levels in the bottom ice may fluctuate greatly during a diurnal cycle. Therefore, the concentrations of nutrients from this study might be overestimated or underestimated since the bottom ice was collected at one time of day.

\section{Effect of Light Intensity on Productivity}

As expected, the carbon uptake rates of bottom ice algae and underlying phytoplankton increased as the incubation depth through the ice hole decreased and consequently light intensity increased (Fig. 3). After the peaks, the carbon uptake rates decreased. The uptake rates of phytoplankton had patterns similar to those of ice algae except in June, when the phytoplankton uptake rate kept increasing as light increased. Similarly, the nitrate uptake rates of ice algae and phytoplankton generally increased as light intensity increased (Fig. 4). The uptake rates of phytoplankton tended to peak under higher light intensities than those of ice algal uptake. The maximum values of nitrate-specific uptake rates for ice algae were two to three times as high as those of phytoplankton for the three observation periods. Since the light intensities at the different depths within the ice were measured around local noon for each incubation, care must be taken when comparing the light intensities and derived parameters presented in Figures 3 and 4 with results from other studies. 
a) bottom ice algae

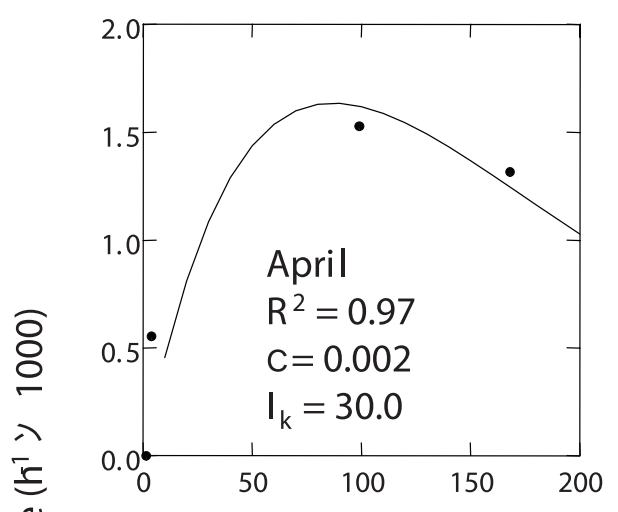

b) phytoplankton

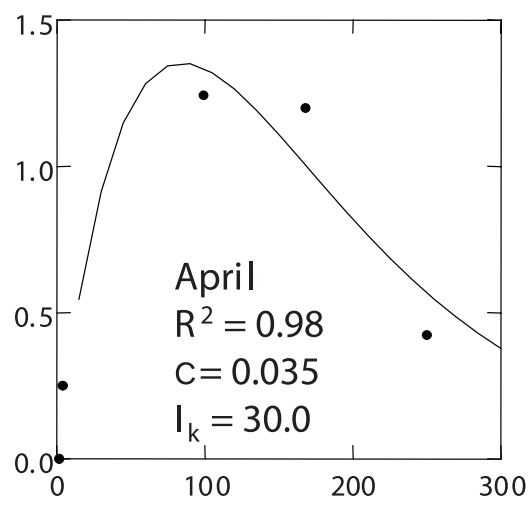

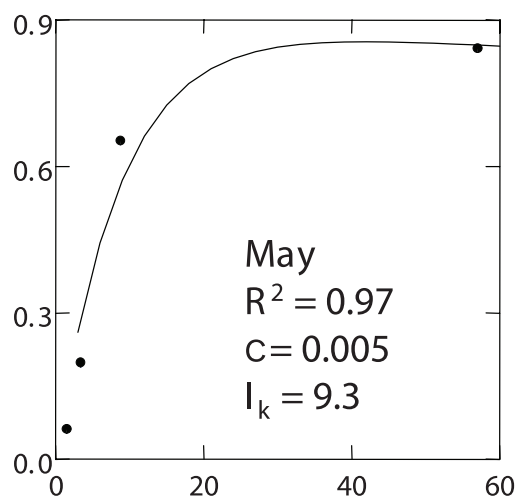

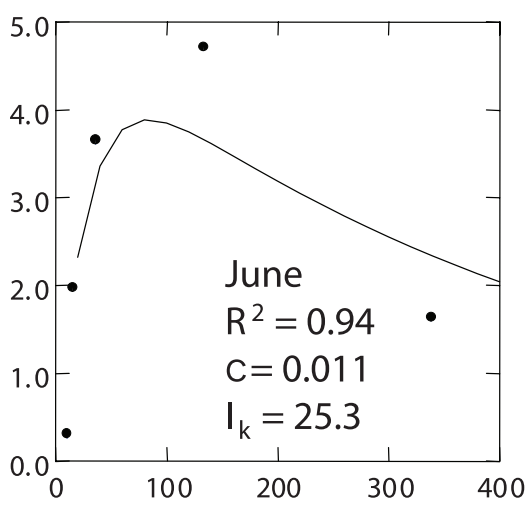

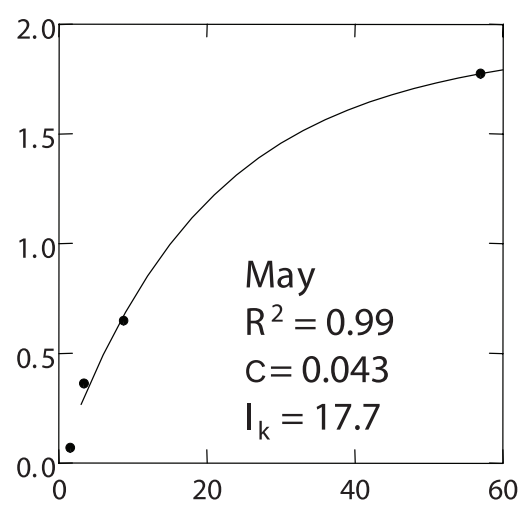

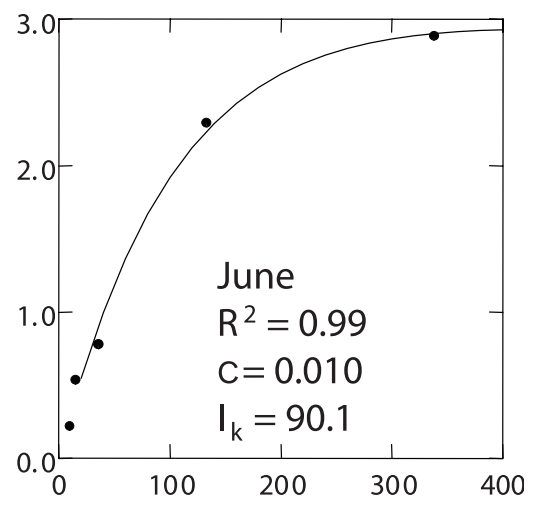

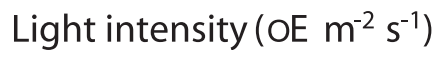

FIG. 3. Carbon specific uptakes of (a) bottom ice algae and (b) phytoplankton at different light intensities on 28 April, 20 May, and 9 June 2003. $\alpha$ : photosynthetic efficiency $\left(\mathrm{mg} \mathrm{C}(\mathrm{mg} \mathrm{Chl} \mathrm{a})^{-1}\left(\mu \mathrm{E} \mathrm{m}^{-2} \mathrm{~s}^{-1}\right)^{-1} \mathrm{~h}^{-1}\right), \mathrm{I}_{\mathrm{k}}$ : photoacclimation parameter $\left(\mu \mathrm{E} \mathrm{m}^{-2} \mathrm{~s}^{-1}\right)$. Note the different vertical scales in the graphs.

TABLE2. Inorganic nutrient concentrations at 2 m under the sea ice and in the ice bottom layer $(3 \mathrm{~cm})$.

\begin{tabular}{llrrrr}
\hline \hline & & \multicolumn{4}{c}{ Concentration $(\mu \mathrm{M})$} \\
\cline { 3 - 6 } & Time & $\mathrm{NO}_{3}$ & $\mathrm{NH}_{4}$ & $\mathrm{SiO}_{4}$ & $\mathrm{PO}_{4}$ \\
\hline \multirow{2}{*}{ Water $(2 \mathrm{~m})$} & 28 April & 6.5 & 3.2 & 24.8 & 1.5 \\
& 20 May & 7.3 & 1.5 & 30.4 & 1.2 \\
\multirow{3}{*}{ Ice Bottom $(3 \mathrm{~cm})$} & 9 June & 2.2 & 0.8 & 15.8 & 0.4 \\
& 28 April & 45.8 & 8.6 & 12.8 & 15.0 \\
& 20 May & 5.2 & 3.5 & 5.8 & 2.4 \\
& 9 June & 0.3 & 10.0 & 2.8 & 0 \\
\hline \hline
\end{tabular}

\section{Effect of Nutrient Concentrations on Productivity}

In general, the carbon-specific uptake rates of ice algae and phytoplankton appeared to decrease after additions of nutrients, although the decreases were not significant (Table 3). The concentrations of nitrate and ammonium at the maxima of carbon uptake rates of phytoplankton and ice algae were similar to those of nitrate and ammonium in the water column and the bottom of the ice, except that the carbon uptake rate in $\mathrm{NO}_{3}$ enrichment on 28 April is higher because of high nitrate concentration in the bottom ice (Table 2).

\section{Light Intensity and Photosynthetic Carbon Allocations}

Photosynthetic carbon allocations into different macromolecules of bottom-ice algae from the different depths of the ice hole are shown in Table 4. At the $1.4 \mathrm{~m}$ depth in the ice, relative carbon allocations into LMWM (54\%) and proteins (38\%) were much greater than allocations into polysaccharides and lipids. When ice algae were incubated at the $1.0 \mathrm{~m}$ depth of the ice hole, LMWM and proteins were still the predominant carbon allocated-macromolecules. At the $0.5 \mathrm{~m}$ depth, the allocation of LMWM increased to $69 \%$ of the total allocation, whereas the protein allocation decreased to $13 \%$. For lipids, more carbon allocation was observed at the 0.5 and $1.0 \mathrm{~m}$ depths of ice than at the $1.4 \mathrm{~m}$ depth. The polysaccharide proportion did not vary between different depths.

\section{DISCUSSION}

\section{Light or Nitrogen Limitation}

The carbon and nitrogen uptake experiments under different light intensities showed that the production rates 
a) bottom ice algae

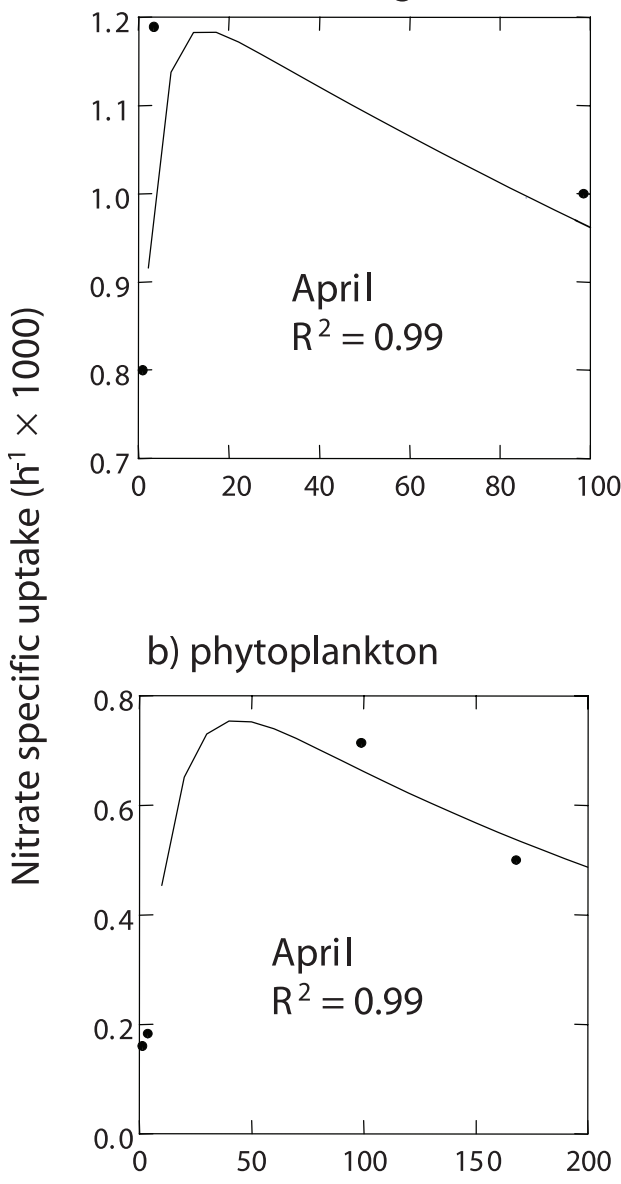

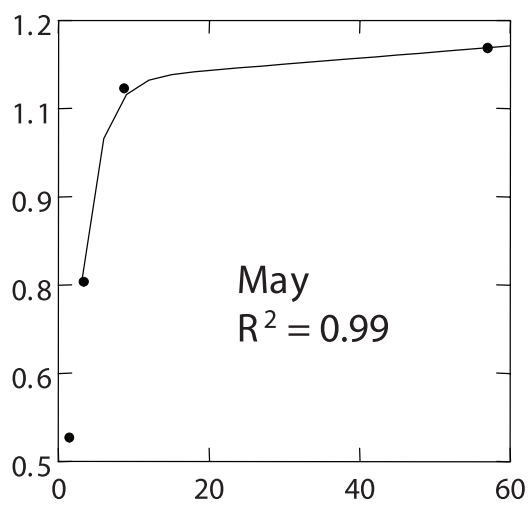

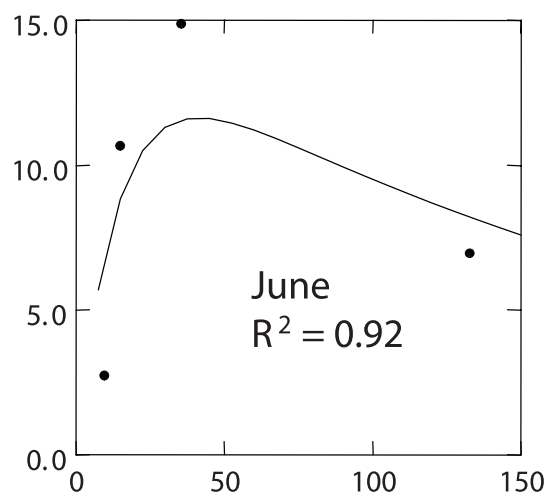

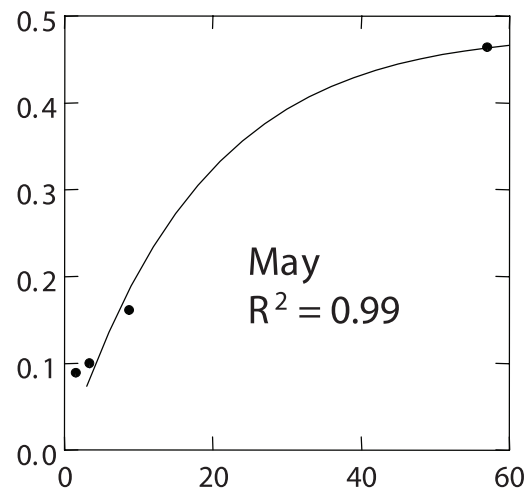

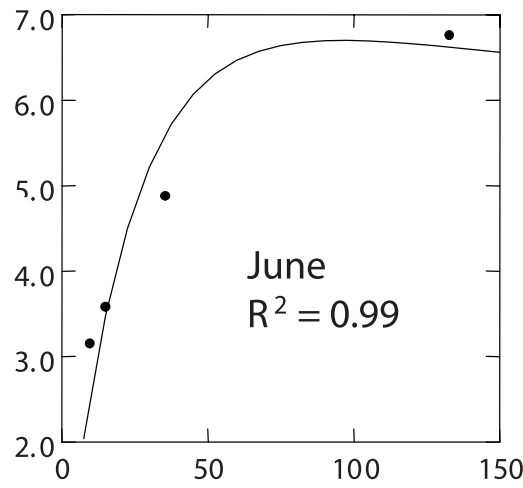

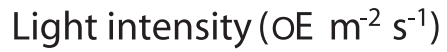

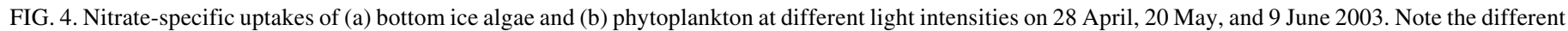
vertical scales in the graphs.

of both ice algae and phytoplankton were evidently enhanced by increased light intensities until reaching light inhibition (Figs. 3 and 4). In contrast, the rates did not increase with the addition of nitrate and ammonium. Rather, the regression models appeared to decrease under higher concentrations of the nutrients, but the statistical analysis (t-test) showed that the decreases were not significant (Table 3). This could result from some methodological problem such as stringing the incubation bottles under each other in the water column (Fig. 2b), which would shade those beneath and cause light-limited carbon uptakes. However, if the bottom ice algae were more limited by nitrogen than by light, their carbon uptakes would increase under more nutrient conditions with light conditions relatively lower than in situ from the shading. In addition, during the observation period there were no substantial depletions in nitrate and ammonium concentrations in the bottom section of the ice (Table 2). The lowest concentration of nitrate was $0.3 \mu \mathrm{M}$ on 9 June 2003 , but the concentration in the brine channels where the ice algae reside is higher than the value from the melted ice cores (Alexander et al., 1974). The concentrations of nutrients at the maxima of carbon uptake rates of ice algae and phytoplankton were slightly higher than those of nutrients measured on water samples and melted samples from the bottom of the ice except on 28 April, when the nitrate concentration in the bottom of the ice was $45.8 \mu \mathrm{M}$, perhaps as a result of brine drainage, microbial activity (Horner and Schrader, 1982), or leakage from the cells (Smith and Sakshaug, 1990). The results suggest that during the study period ice algae and phytoplankton were not limited by in situ nitrogen and the nitrogen was likely sufficient under light limitation since the carbon uptake rates of ice algae and phytoplankton increased as light intensity increased. The mean assimilated $\mathrm{C} / \mathrm{N}$ ratios, which at 3.9 for ice algae and 3.3 for phytoplankton were lower than the Redfield ratio (6.6), support the idea that these algae were not nitrogen-limited. But the particulate $\mathrm{C} / \mathrm{N}$ ratios were higher (10.5 for phytoplankton and 8.7 for ice algae) than the Redfield ratio, probably because of the effect of detritus, carbon excretion of dissolved organic carbon, or possibly production of exopolymeric substances (Krembs et al., 2002). Unfortunately, the experiment on the productivity of ice algae or phytoplankton under increments of both light and nitrogen was not performed. Instead of nitrate or ammonium, $\mathrm{PO}_{4}$ might be a possible limitation for the ice algae at the 
TABLE 3. Summary of regression models relating carbon-specific uptake rates (Y) of bottom ice algae and phytoplankton to different nitrate and ammonium concentrations (X) from the nutrient enrichment experiments on 28 April, 20 May, and 9 June 2003 . All models are of the form $\mathrm{Y}=\mathrm{aX}+\mathrm{b} ; p$ is $p$-value, and $\mathrm{n}$ is sample number.

\begin{tabular}{|c|c|c|c|c|c|c|c|c|c|c|c|c|}
\hline & \multicolumn{4}{|c|}{28 April } & \multicolumn{4}{|c|}{20 May } & \multicolumn{4}{|c|}{9 June } \\
\hline & \multicolumn{2}{|c|}{ Ice algae } & \multicolumn{2}{|c|}{ Phytoplankton } & \multicolumn{2}{|c|}{ Ice algae } & \multicolumn{2}{|c|}{ Phytoplankton } & \multicolumn{2}{|c|}{ Ice algae } & \multicolumn{2}{|c|}{ Phytoplankton } \\
\hline & $\mathrm{NO}_{3}$ & $\mathrm{NH}_{4}$ & $\mathrm{NO}_{3}$ & $\mathrm{NH}_{4}$ & $\mathrm{NO}_{3}$ & $\mathrm{NH}_{4}$ & $\mathrm{NO}_{3}$ & $\mathrm{NH}_{4}$ & $\mathrm{NO}_{3}$ & $\mathrm{NH}_{4}$ & $\mathrm{NO}_{3}$ & $\mathrm{NH}_{4}$ \\
\hline $\mathrm{a}$ & -0.000010 & -0.000050 & -0.000003 & -0.000007 & -0.000020 & -0.000020 & -0.000005 & -0.000005 & -0.000003 & 0.000200 & -0.000020 & -0.000010 \\
\hline $\mathrm{b}$ & 0.00080 & 0.00011 & 0.00020 & 0.00020 & 0.00004 & 0.00004 & 0.00010 & 0.00020 & 0.00200 & 0.00210 & 0.00070 & 0.00060 \\
\hline $\mathrm{R}^{2}$ & 0.40 & 0.40 & 0.18 & 0.53 & 0.55 & 0.44 & 0.40 & 0.23 & 0.32 & 0.49 & 0.46 & 0.20 \\
\hline$p$ & 0.18 & 0.40 & 0.41 & 0.10 & 0.10 & 0.15 & 0.18 & 0.33 & 0.43 & 0.30 & 0.14 & 0.37 \\
\hline $\mathrm{n}$ & 7 & 7 & 7 & 7 & 7 & 7 & 7 & 7 & 7 & 7 & 7 & 7 \\
\hline
\end{tabular}

bottom of the ice (Haecky and Andersson, 1999). On 9 June 2003, the concentration of $\mathrm{PO}_{4}$ was undetectable at the bottom section of the ice and relatively low in the water (Table 2). Unfortunately, there was no $\mathrm{PO}_{4}$ enrichment experiment for the carbon uptake of the bottom ice algae.

Numerous studies have shown that light is the major limiting factor in the onset and early development of ice algal blooms at the bottom of ice (Horner, 1985; Cota and Smith, 1991; Smith et al., 1993; Haecky and Andersson, 1999; Lavoie et al., 2005). However, in the light increment experiment on 9 June 2003, the carbon uptake rate of ice algae was still enhanced by increased light intensities. This suggests that the production of ice algae might be lightlimited through the sea ice season at Barrow, although the light limitation effects vary between regions and times because of differences in ice thickness and snow cover.

\section{Photosynthetic Carbon Partitioning into Macromolecules}

When the biomass of the bottom ice algae was highest on 28 April 2003 (Table 1), the proportion of LMWM production was $47-69 \%$ for different depths of the ice hole (Table 4). The high proportion of carbon allocation into LMWM has been previously reported for the ice algae community (Smith et al., 1987; Mock and Gradinger, 2000) as well as for phytoplankton of the Southern Ocean (Barlow and Henry, 1982). There are several possible reasons for the high LMWM allocation of ice algae. First, certain amino acids, sugars, or sugar alcohol might accumulate as a result of osmo-regulatory or cold-resistance functions (Franks, 1985; Smith et al., 1987). The temperature in the bottom parts of the ice cores was nearly constant at around $-1.5^{\circ} \mathrm{C}$ during the observation period from 28 April to 9 June 2003 (Table 1). However, we found that the LMWM proportion of ice algae decreased through the season (Lee, 2005). The alternative is related to the dominant pathway of the production of LMWM, which is the precursor of macromolecules such as free amino acids and carbohydrates as storage forms, under sufficient nutrient conditions (Smith et al., 1989; Lindqvist and Lignell, 1997; Mock and Gradinger, 2000). Conover (1975) and Dortch et al. (1984) described the storage of free amino acids in diatom cells. The predominant ice algae community is believed to be large, chain-forming diatoms at
Barrow (Alexander et al., 1974) found under sufficient nutrient conditions when the biomass of the bottom ice algae was highest on 28 April.

Under higher light conditions at 0.5 and $1.0 \mathrm{~m}$ depths into the hole, the relative proportion of protein production decreased compared to the $1.4 \mathrm{~m}$ depth, whereas the lipid proportion increased somewhat. The tendency for carbon incorporation into proteins of ice algae to decrease with increasing light is consistent with results for marine phytoplankton (Morris, 1981; Fernández et al., 1994; Suárez and Marañón, 2003) and freshwater phytoplankton (Hama et al., 1990), as well as for Arctic ice algae (Smith et al., 1989). In contrast, allocation to lipids was positively related to light intensity, as has been shown for Arctic ice algae (Smith et al., 1987). Our results are very similar to those of Smith et al. (1989) for Resolute Passage in the central Canadian Arctic, although their incubation method was different from that in this study: they scraped algae from ice samples directly into filtered seawater and incubated them under fluorescent lighting of various intensities. Given the ongoing decrease in sea ice extent and thickness, the higher lipid synthesis of the bottom ice algae incubated at the shallower depths of the ice hole might be significant to the current or future nutritional status of zooplankton and benthic fauna. Because lipids are the most calorie-rich biomolecules, their production by primary producers are a critical energy source for higher trophic levels (Wainman and Lean, 1992).

\section{SUMMARY AND CONCLUSIONS}

This study examined the effects of different light and nitrogen conditions on rates of production and photosynthetic parameters of ice algae and phytoplankton under the snow-covered sea ice in a landfast sea-ice zone at Barrow, Alaska. The results indicated that light, rather than $\mathrm{NO}_{3}$ or $\mathrm{NH}_{4}$ concentration, was a main limiting factor for their rates of production. Also, higher light conditions increased lipid synthesis by the bottom ice algae, but lowered protein production.

However, solving some methodological problems will improve future studies. The nutrient concentrations in melted ice cores can be very different from the concentrations in 
TABLE 4. Photosynthetic carbon allocations into different macromolecules of the bottom ice algae at three depths into the ice hole on 28 April 2003.

\begin{tabular}{ccccc}
\hline \hline & \multicolumn{4}{c}{ Percent of Photosynthate } \\
\cline { 2 - 5 } Depth into ice hole (m) & LMWM $^{1}$ & Lipid & Protein & Polysaccharide \\
\hline 0.5 & 69.1 & 11.9 & 13.4 & 5.6 \\
1.0 & 46.8 & 13.9 & 34.8 & 4.5 \\
1.4 & 53.8 & 3.8 & 37.6 & 4.8 \\
\hline \hline
\end{tabular}

${ }^{1}$ LMWM = low-molecular-weight metabolites.

the brine channels where the algae live. It would be better to measure concentrations in the brine by separating the brine from the core before melting, using centrifugation. Then $\mathrm{PO}_{4}$ concentrations in the brine might provide some idea about the possible $\mathrm{PO}_{4}$ limitation for the bottom ice algae. $\mathrm{PO}_{4}$ is known to be an important potential limiting factor for some algal communities (Haecky and Andersson, 1999). Therefore, $\mathrm{PO}_{4}$ enrichment experiments along with those on nitrogen enrichment would be very helpful to understand any nutrient limitation on ice algae and phytoplankton productions at Barrow. In regard to light measurements, light intensity through sea-ice holes or at the sea-ice bottom should be carefully measured with better tools (e.g., using an under-ice arm to minimize the ice hole effect on the light field). Many attenuation possibilities must be considered, since light intensity is very low at the bottom sea ice and is greatly affected by different conditions such as snow cover and ice hole.

For better understanding of phytoplankton and ice algae production in the entire Arctic Ocean under ongoing changes in the sea ice thickness and extent, more biophysical time series observations for ice algae and underlying phytoplankton are needed in different types of sea ice in many different regions of the Arctic Ocean. Ice algae and phytoplankton might have different growth conditions at different locations, especially for coastal and oceanic environments. Moreover, an intensified study on light intensities under different conditions (such as melting and frozen snow cover and sediment trapped within sea ice) is necessary since light is an important factor in controlling production.

\section{ACKNOWLEDGEMENTS}

We thank the people from the Barrow Arctic Science Consortium (BASC) for their supporting facilities at Barrow and Dr. Naoki Uzuka and Dr. Celin Gueguen from the Institute of Arctic Research Center (IARC) at the University of Alaska Fairbanks for getting the bottom ice algae on the sea ice. We are especially indebted to Dr. Rolf Gradinger for helping in the support of our field experiments and for sharing his brilliant ideas during the observation periods. We much appreciate the constructive comments by three reviewers, which greatly improved an earlier version of the manuscript. This research was supported by grants from the Frontier Research
System for global change from IARC and by the NOAA Ocean Exploration and Arctic Research Offices through Cooperative Institute for Arctic Research grants. We also appreciate the financial support from the Korea Polar Research Institute (PE07060 and PM07020) to complete the manuscript.

\section{REFERENCES}

ALEXANDER, V. 1980. Interrelationships between the seasonal sea ice and biological regimes. Cold Regions Science and Technology Report 2:157-178.

ALEXANDER, V., and CHAPMAN, T. 1981. The role of epontic algal communities in Bering Sea ice. In: Hood, D.W., and Calder, J.A., eds. The Eastern Bering Sea Shelf: Oceanography and resources. Seattle: University of Washington Press. $773-780$.

ALEXANDER, V., HORNER, R.A., and CLASBY, R.C. 1974. Metabolism of Arctic sea ice organisms. Report R74-4. Fairbanks: Institute of Marine Science, University of Alaska. 120 p.

APOLLONIO, S. 1965. Chlorophyll in Arctic sea ice. Arctic 18:118-122.

ARRIGO, K.R. 2003. Primary production in sea ice. In: Thomas, D.N., and Dieckmann, G.S., eds. Sea ice: An introduction to its physics, chemistry, biology and geology. Oxford: Blackwell. $143-183$.

ARRIGO, K., WORTHEN, D.L., LIZOTTE, M.P., DIXON, P., and DIECKMANN, G. 1997. Primary production in Antarctic sea ice. Science 276:394-397.

BARLOW, R.G., and HENRY, J.L. 1982. Patterns of carbon assimilation in phytoplankton from the Southern Ocean. Fisheries Bulletin of South Africa 16:25-29.

COMISO, J.C. 2006. Arctic warming signals from satellite observations. Weather 61:70-76.

CONOVER, S.A.M. 1975. Partitioning of nitrogen and carbon in cultures of the marine diatom Thalassiosira fluviatilis supplied with nitrate, ammonium or urea. Marine Biology 32:231 - 246.

COTA, G.F., and SMITH, R.E.H. 1991. Ecology of bottom ice algae: Comparative physiology. Journal of Marine Systems 2:297-315.

DORTCH, Q., CLAYTON, J.R., Jr., THORESEN, S.S., and AHMED, S.I. 1984. Species differences in accumulation of nitrogen pools in phytoplankton. Marine Biology 81:237-250.

DUGDALE, R.C., and GOERING, J.J. 1967. Uptake of new and regenerated forms of nitrogen in primary productivity. Limnology and Oceanography 12:196-206.

FERNÁNDEZ, E., MARAÑÓN, E., HARBOUR, D.S., and PINGREE, R.D. 1994. Phytoplankton carbon incorporation patterns of particulate matter in the eastern North Atlantic subtropical region. Journal of Plankton Research 16: $1627-1644$.

FRANKS, F. 1985. Biophysics and biochemistry at low temperatures. Cambridge: Cambridge University Press. 210 p.

GOSSELIN, M., LEGENDRE, L., THERRIAULT, J.C., and DEMERS, S. 1990. Light and nutrient limitation of sea-ice microalgae (Hudson Bay, Canadian Arctic). Journal of Phycology 26:220-232. 
GOSSEliN, M., LEVASSEUR, M., WHEELER, P.A., and BOOTH, B.C. 1997. New measurements of phytoplankton and ice algal production in the Arctic Ocean. Deep-Sea Research 44:1623-1644.

HAECKY, P., and ANDERSSON, A. 1999. Primary and bacterial production in sea ice in the northern Baltic Sea. Aquatic Microbial Ecology 20:107-118.

HAMA, T., MIYAZAKI, T., OGAWA, Y., IWAKUMA, T., TAKAHASHI, M., OTSUKI, A., and ICHIMURA, S. 1983. Measurement of photosynthetic production of a marine phytoplankton population using a stable ${ }^{13} \mathrm{C}$ Isotope. Marine Biology 73:31-36.

HAMA, T., MATSUNAGA, K., HANDA, N., and TAKAHASHI, M. 1990. Composition of photosynthetic products in Lake Biwa, Japan: Vertical and seasonal changes and their relation to environmental factors. Journal of Plankton Research 12:133-147.

HORNER, R.A. 1985. Ecology of sea ice microalgae. In: Horner, R., ed. Sea ice biota. Boca Raton, Florida: CRC Press. 83-103.

HORNER, R., and SCHRADER, G.C. 1982. Relative contributions of ice algae, phytoplankton, and benthic microalgae to primary production in nearshore regions of the Beaufort Sea. Arctic 35:485-503.

KREMBS, C., EICKEN, H., JUNGE, K., and DEMING, J.W. 2002. High concentrations of exopolymeric substances in Arctic winter sea ice: Implications for the polar ocean carbon cycle and cryoprotection of diatoms. Deep Sea Research Part I 49: 2163-2181.

LAVOIE, D., DENMAN, K., and MICHEL, C. 2005. Modeling ice algae growth and decline in a seasonally ice-covered region of the Arctic (Resolute Passage, Canadian Archipelago). Journal of Geophysical Research 110, C11009, doi:10.1029/ 2005JC002922.

LAXON, S., PEACOCK, N., and SMITH, D. 2003. High interannual variability of sea ice thickness in the Arctic region. Nature 425:947-950.

LEE, S.H. 2005. Current primary production rates of the western Arctic Ocean estimated by stable carbon and nitrogen isotope tracers. PhD thesis, University of Alaska Fairbanks. 217 p.

LEGENDRE, L., INGRAM, R.G., and POULIN, M. 1981. Physical control of phytoplankton production under ice (Manitounuk Sound, Hudson Bay). Canadian Journal of Fisheries and Aquatic Sciences 38:1385-1392.

LI, W.K.W., GLOVER, H.E., and MORRIS, I. 1980. Physiology of carbon photoassimilation by Oscillatoria thiebautii in the Caribbean Sea. Limnology and Oceanography 25(3):447-456.

LINDQVIST, K., and LIGNELL, R. 1997. Intracellular partitioning of ${ }^{14} \mathrm{CO}_{2}$ in phytoplankton during a growth season in the northern Baltic. Marine Ecological Progress Series 152:41-50.

LIZOTTE, M.P. 2001. The contributions of sea ice algae to Antarctic marine primary production. American Zoologist 41:57-73.

MICHEL, C., LEGENDRE, L., INGRAM, R.G., GOSSELIN, M., and LEVASSEUR, M. 1996. Carbon budget of sea-ice algae in spring: Evidence of a significant transfer to zooplankton grazers. Journal of Geophysical Research 101:18345-18360.

MOCK, T., and GRADINGER, R. 1999. Determination of Arctic ice algal production with a new in situ incubation technique. Marine Ecological Progress Series 177:15-26.
2000. Changes in photosynthetic carbon allocation in algal assemblages of Arctic sea ice with decreasing nutrient concentrations and irradiance. Marine Ecological Progress Series 202:1-11.

MORRIS, I. 1981. Photosynthetic products, physiological state, and phytoplankton growth. Canadian Bulletin of Fisheries and Aquatic Sciences 210:83-102.

PARSONS, T.R., MAITA, Y., and LALLI, C.M. 1984. A manual of chemical and biological methods for seawater analysis. New York: Pergamon Press. 173 p.

PLATT, T., GALlEGOS, C.L., and HARRISON, W.G. 1980. Photoinhibition of photosynthesis in natural assemblages of marine phytoplankton. Journal of Marine Research 38: $687-701$.

ROTHROCK, D.A., YU, Y., and MAYKUT, G.A. 1999. Thinning of the Arctic sea-ice cover. Geophysical Research Letters 26(23):3469-3472.

ROTHROCK, D.A., ZHANG, J., and YU, Y. 2003. The Arctic ice thickness anomaly of the 1990s: A consistent view from observations and models. Journal of Geophysical Research 108(C3), 3083, doi:10.1029/2001JC001208.

SERREZE, M.C., MASLANIK, J.A., SCAMBOS, T.A., FETTERER, F., STROEVE, J., KNOWLES, K., FOWLER, C., DROBOT, S., BARRY, R.G., and HARAN, T.M. 2003. A record minimum Arctic sea ice extent and area in 2002. Geophysical Research Letters 30(3), 1110, doi:10.1029/ 2002 GL016406.

SMITH, R.E.H., CLEMENT, P., COTA, G.F., and LI, W.K.W. 1987. Intracellular photosynthate allocation and the control of Arctic marine ice-algal production. Journal of Phycology 23: $124-132$.

SMITH, R.E.H., ANNING, A., CLEMENT, P., and COTA, G. 1988. Abundance and production of ice algae in Resolute Passage, Canadian Arctic. Marine Ecological Progress Series 48:251-263.

SMITH, R.E.H., CLEMENT, P., and HEAD, E. 1989. Biosynthesis and photosynthate allocation patterns of High Arctic ice algae. Limnology and Oceanography 34:591-605.

SMITH, R.E.H., CAVALETTO, J.F., EADIE, B.J., and GARDNER, W.S. 1993. Growth and lipid composition of High Arctic ice algae during the spring bloom at Resolute, Northwest Territories, Canada. Marine Ecological Progress Series 97:19-29.

SMITH, R.E.H., GOSSELIN, M., and TAGUCHI, S. 1997. The influence of major inorganic nutrients on the growth and physiology of High Arctic ice algae. Journal of Marine Systems 11:63-70.

SMITH, W.O., and SAKSHAUG, E. 1990. Polar phytoplankton. In: Smith, W.O., ed. Polar oceanography, Part B. San Diego: Academic Press. 475-525.

SOOHOO, J.B., PALMISANO, A.C., KOTTMEIER, S.T., LIZOTTE, M.P., SOOHOO, S.L., and SULLIVAN, C.W. 1987. Spectral light absorption and quantum yield of photosynthesis in sea ice microalgae and a bloom of Phaeocystis pouchetii from McMurdo Sound, Antarctica. Marine Ecological Progress Series 39:175-189.

SUÁREZ, I., and MARAÑÓN, E. 2003. Photosynthate allocation in a temperate sea over an annual cycle: The relationship 
between protein synthesis and phytoplankton physiological state. Journal of Sea Research 20:285-299.

TAGUCHI, S., and SMITH, R.E.H. 1997. Effect of nitrogen and silicate enrichment on photosynthate allocation by ice algae from Resolute Passage, Canadian Arctic. Journal of Marine Systems 11:53-61.

TYNAN, C.T., and DeMASTER, D.P. 1997. Observations and predictions of Arctic climatic change: Potential effects on marine mammals. Arctic 50:308-322.

VINNIKOV, K.Y., ROBOCK, A., STOUFFER, R.J., WALSH, J.E., PARKINSON, C.L., CAVALIERI, D.J., MITCHELL, J.F.B., GARRETT, D., and ZAKHAROV, V.F. 1999. Global warming and Northern Hemisphere sea ice extent. Science 286:1934-1937.
WAINMAN, B.C., and LEAN, D.R.S. 1992. Carbon fixation into lipid in small freshwater lakes. Limnology and Oceanography 37(5):956-965.

WEBB, D.J., BURNISON, B.K., TRIMBEE, A.M., and PREPAS, E.E. 1992. Comparison of chlorophyll a extractions with ethanol and dimethyl sulfoxide/acetone, and a concern about spectrophotometric phaeopigment correction. Canadian Journal of Fisheries and Aquatic Sciences 49:2331-2336.

WHITLEDGE, T.E., MALLOY, S.C., PATTON, C.J., and WIRICK, C.D. 1981. Automated nutrient analysis in seawater. Technical Report BNL 51398. Upton, New York: Brookhaven National Laboratory, U.S. Department of Energy. 